\title{
NEW ZEALAND AND \\ ARTICLES 6, 7 AND 8 OF THE \\ INTERNATIONAL COVENANT \\ ON ECONOMIC, SOCIAL AND \\ CULTURAL RIGHTS: \\ HOW ARE WE DOING AND \\ COULD WE DO BETTER?
}

\author{
Amanda Reilly \\ School of Accounting and Commercial Law \\ Victoria University of Wellington
}

\begin{abstract}
This paper will focus on Articles 6, 7 and 8 of the International Covenant on Economic, Social and Cultural Rights which confer respectively: the right to work, the right to the enjoyment of just and favourable conditions of work, and the right to form and join trade unions. It is argued that while, overall New Zealand has a strong domestic framework of legislation giving effect to these rights, there are some specific areas of present, and possible future, concern. Various aspects of New Zealand law and policy and some International Conventions which align with, and strengthen, Articles 6, 7 and 8 are examined and it is concluded that:
\end{abstract}

- The right to work is a right to freely chosen work. On particular implication of this is that New Zealand needs to be careful about putting prisoners to work.

- The right to work includes a right to protection from unfair dismissal.

- Some groups in New Zealand suffer from discrimination, not only in accessing work but in enjoying equal opportunities and the rights which should attach to work

- $\quad$ Ongoing progress towards ratifying International Labour Organisation Conventions 87 and 138 is desirable.

\section{Introduction}

\section{Explanation of Articles 6,7 and 8}

This paper will focus on Articles 6, 7 and 8 of the International Covenant on Economic, Social and Cultural Rights (1966) (hereafter ICESCR) ISCESCR is part of the United Nations International Bill of Human Rights together with, the Universal Declaration of Human Rights (1948) and the International Covenant on Civil and Political Rights (1966). Together these documents are the focus, and framework, of United Nations efforts to promote, protect and monitor Human Rights.

Articles 6, 7 and 8 of the ICESCR are respectively: the right to work, the right to the enjoyment of just and favourable conditions of work, and the right to form and join trade unions. These are now explained in more detail:

Article 6 recognises the right to work. This includes the right to the opportunity to gain a living by work which is freely chosen or accepted. The language of Article 6 makes it clear that it refers to work of a paid nature whether it be as an employee or a self employed worker. While it is not an absolute right it does require the state to take various steps to achieve the realisation of this right including training programmes and generally pursuing economic, social and cultural development policies while safeguarding fundamental political and economic freedoms.

Article 7 recognises the right of everyone to the enjoyment of just and favourable conditions of work

- $\quad$ including fair wages sufficient to provide a decent living for individuals and their families

- non discrimination including equal pay for equal work, and equal opportunity for promotion, in particular for women.

- Safe and healthy working conditions;

- $\quad$ Equal opportunity for promotion

- $\quad$ Rest, leisure and reasonable limitation of working hours and periodic holidays with pay, as well as remuneration for public holidays.'

Article 8 recognises the right to join and form trade unions and includes the right to strike provided it is exercised in conformity with the laws of the particular nation in question. 
While discussion here will primarily focus on Articles 6 , 7 and 8 a raft of other Conventions are also relevant as they align with, and strengthen the ICESR rights. ${ }^{2}$

Having explained the content of the Articles it is now necessary to explain their relevance and potential uses. Following this explanation some areas where New Zealand could do better, or which are of possible future concern, will be identified and described. The paper will conclude with some suggestions for future work arising out of this research.

\section{The relevance, and uses, of the rights established by Articles 6, 7 and 8 .}

Articles 6,7 and 8 can potentially be used in a variety of ways to protect and enhance the quality of working life in New Zealand. ICESR was ratified by New Zealand in 1978. New Zealand has therefore assumed an obligation to uphold the rights established by ICESR. In particular Article 2 of ICESR imposes a duty on all parties to take steps to the maximum of available resources towards progressively realising the rights in the Covenant. Deliberately regressive measures which impede the realisation of rights are ruled out. ${ }^{3}$

New Zealand is required to submit regular reports to the ICESR Committee outlining the legislative, judicial, policy and other measures they have taken to implement the rights affirmed in the Covenant every five years. The Committee will examine this report and address its concerns and recommendations to the State party in the form of "concluding observations." While no mechanism exists to penalise countries, where the concluding observations suggest serious issues, the observations can still be used for the purposes of naming, blaming and shaming which can lead to law and policy changes.

At present there is no formal complaints process whereby individuals or groups who feel that their rights have been violated can complain to the Committee. Nonetheless the Committee has repeatedly invited NGOs to submit to it in writing, at any time, information regarding any aspect of its work.

Judges and other law enforcement authorities could also potentially use the rights, here discussed, to protect and enhance working conditions. The United Nations Economic and Social Council has, in particular, invited Judges and other law enforcement authorities to pay greater attention to violations of international rights in the exercise of their functions. ${ }^{5}$

However, apart from taking advantage of the formal legal status of Articles 6,7 and 8 , and attendant processes another way that the language of work rights might be more utilised is for rhetorical persuasive purposes. ${ }^{6}$ Rights provide a language for the expression of aspiration and a focus of moral claims. They could potentially be used to persuade individual employers to voluntarily reflect on, and perhaps modify, their practices. Compa describes how, in response to public and consumer pressure, a number of international companies such as Reebok and Nike, developed their own internal codes of conduct utilising various international human rights instruments. ${ }^{7}$
He reports that there have been concrete, positive results resulting from the application of such corporate sponsored codes of conduct ${ }^{8}$. He suggests that "a reputation for good workplace practices and high labor standards can be a powerful "brand" asset for companies and for countries in the global economy." 9 It is possible that rights based arguments may prove compelling to some employers purely on the bases of the moral claims they articulate. ${ }^{10}$

Having explained the relevance of Articles 6,7 and 8 there will now be some discussion of areas of present, and possible future concern in New Zealand.

\section{Areas of concern: Article 6}

\section{Access to Work}

Article 6 establishes a right to gain a living by work. It is therefore of concern that the Human Rights Commission reports ${ }^{11}$ that ongoing structural disadvantages limit the participation of some disadvantaged groups in the labour market. Maori and Pacific peoples have higher unemployment rates than the general community at $7.2 \%$ and $6.8 \%$ respectively. They also report that refugees and ethnic communities face difficulties accessing appropriate employment and that there is continuing systemic discrimination and prejudice against job seekers on the basis of Chinese and Indian names. Mature job seekers encounter prejudice and it seems that ageism is pervasive in the workplace. Disabled people encounter stigma and unlawful discrimination. Young people entering work face specific barriers. Men and women returning to the workforce after full time family responsibilities also experience difficulties accessing employment.

New Zealand can, and should, do better in these areas. This is an issue not just in terms of meeting the obligation of a right to work under Article 6 but also potentially of Article 7, which recognises the right of everyone to the enjoyment of just and favourable conditions of work and to non discrimination including equal pay for equal work.

\section{Right to Protection from Unfair Dismissal}

It should be noted that the right to work not only includes a right to the opportunity to access work it also includes a right to protection against unfair dismissal. ${ }^{12}$ This is expanded on by ILO Convention No 158 concerning Termination of Employment (1982) which defines the lawfulness of dismissal in article 4 and in particular imposes the requirement to provide valid grounds for dismissal as well as the right to legal and other redress in the case of unjustified dismissal.

New Zealand legislation currently provides protection from unfair dismissal and the ability to bring a Personal Grievance under s 103, at least for those who fit within the definition of employee under section 6 of the Employee Relations Act 2000 Should these rights in the future be watered for down it may be arguable that this is contrary to the right to work. 


\section{Work Should Be Freely Chosen or Accepted}

Another important point about the right to work is that Article 6 states that work is to be freely chosen or accepted. Article 6 thus provides no support for forced participation in work even if participation is framed as being for the benefit of the coerced workers.

While not current policy in New Zealand workfare practices where benefits are tied to compulsory employment schemes or where the level of benefit is reduced when recipients refuse to participate in employment schemes are a situation where work cannot be said to be freely chosen. ${ }^{13}$ Similarly requiring solo parents to take part in a certain number of hours of paid work per work has to be seen as coercive. It should also be noted that Article 11 of the International Covenant on Economic, Social and Cultural Rights separately guarantees an adequate standard of living which is not contingent on paid work.

One particular area, there is currently reason to be vigilant for breaches of this right is in the area of prison labour. The Corrections Inmate Employment (CIE) programme 51 per cent of the total prison population and 66 per cent of sentenced inmates involved in employment or training. ${ }^{14}$

The rationale for prisoners having the opportunity to work in prison is sensible and humane. There is a correlation between low skill levels and unemployment and criminal convictions. The last prison census (2003) revealed that 52 per cent of prisoners had no formal qualifications and only 45 per cent were in paid work before going to prison. ${ }^{15}$ Work can assist in prisoner rehabilitation. Gaining skills and qualifications increases the chances of prisoners finding jobs following their release and thus decreases the chances of prisoners reoffending.

However, in terms of New Zealand's international human rights obligations there is reason to be concerned about the implementation of prison employment schemes. Prison labour is not free labour. ${ }^{16}$ While participation in prison employment schemes in New Zealand is ostensibly voluntary the fact remains that individuals are incarcerated and so the nature of that consent must be questioned. ${ }^{17}$ And the risk of exploitation cannot be denied particularly when prisoners are made available to the private sector. ${ }^{18}$

Thus far discussion here has focused on Article 6 of Convention on Economic, social and cultural rights and the requirement that employment should be freely chosen. However ILO Convention (No. 29) Concerning Forced Labour 1938 is also here relevant. This Convention, in fact, permits forced labour for prisoners in some circumstances but only when the work is carried out "under the supervision and control of a public authority and that the said person is not hired or placed at the disposal of private individuals, companies or associations." ${ }^{19}$ However, in New Zealand some of the work that prisoners do is carried out for the private sector. For example prisoners have been reported to be working as fruit pickers in the Hawkes Bay, ${ }^{20}$ assembling photocopiers for Cannon ${ }^{21}$ and making pre-cast concrete blocks for a private development. ${ }^{22}$

If the rationale for prison labour is that the work is to facilitate rehabilitation then prisoners should only engage in work that will genuinely provide rehabilitation. It has to be questioned whether activities such as fruit picking which is essentially unskilled labour, the performance of which does not provide an opportunity to obtain a qualification, fits this criteria. It is also important that vigilance is exerted to ensure the prison work is genuinely freely chosen and that refusal to work is not punished, for example, by loss of privileges or loss of the chance or early release. ${ }^{23}$ This conclusion is in line with the ILO observation that if privatized prison labour is seen as positive this can only be so if "marketable skills are imparted and prisoners engage in such employment and training on an entirely voluntary basis." 24

One further issue: private prisons are not common in New Zealand but were policy on this to change it should be noted that it would be potentially problematic were prisoners to carry out work under the supervision of the prison in question. In 1998 the Australian Council of Trade Unions complained to the ILO that private prisons in Victoria breached Convention Number 29 as in private prisons the work is supervised by private operators (i.e the prison) and prisoners are required to perform work for a private company (the company managing the prison).

The ILO upheld the complaint. ${ }^{25}$ The committee of Experts on the Application of Conventions and Recommendations (CEACR) said that work exacted from a person as a consequence of a conviction in a court of law is compatible with the convention only if two requirements are met: the work is carried out under the supervision and control of the public authority AND the person is not hired to or placed at the disposal of private individuals and committees. The committee ruled that there is no exception to this prohibition which is absolute and which must be complied with.

Having considered the ramifications of Article 6 and the groups in New Zealand who may find it problematic to exercise their right to work the next section will consider Article 7 and 8.

\section{Areas of Concern: Articles 7 and 8}

Article 7 recognises the right of everyone to the enjoyment of just and favourable conditions of work and the right to non discrimination at work and Article 8 recognises the right to join and form trade unions.

New Zealand has "a strong domestic framework of legislation that recognises the rights of employees in relation to pay, safe working conditions, holidays, employment protection and protection from discrimination" ${ }^{26}$ Clear rights to form and join trade unions are extended to employees by the Employment Relations Act 2000 which lists promoting collective bargaining under section 3 (a) iii as one of its objects.

However, there is still much work to be done to strengthen and enhance the rights established by Article 7 
and 8 . Some groups continue to have difficulty accessing the rights to equality and fair and just conditions of work which should attach to their status as workers.

The groups identified as structurally disadvantaged above under the discussion of the right to work, not only experience difficulty accessing work, but also in terms of outcome where they succeed in obtaining work ${ }^{27}$.

\section{Women}

Article 7 recognises the right of everyone to the enjoyment of just and favourable conditions of work but it particularly emphasizes a right to non discrimination including equal pay for equal work, and equal opportunity for promotion, for women. However, in New Zealand. while progress has been made, women remain disadvantaged.

Occupational segregation of women in lower paid occupations has contributed to New Zealand's pay equality gap with women earning on average 87 cents for every dollar earned by men. Maori and Pacific women earn significantly less than other women. ${ }^{28}$ The 2008 Census of Women's Participation which measure how well New Zealand is doing in participation of women in leadership roles in various fields suggests that there is much progress still to be made. Women continue to be significantly under represented in governance and leadership, the judiciary and the law, media, universities and other areas of public life. ${ }^{29}$

\section{Agency Hire Workers and Temporary Workers}

Also, of concern is the fact that some groups of workers in particular types of working relationships do not enjoy access to all the rights they should be entitled to: One group of particular concern is temporary and agency hire workers i.e. employees in so-called triangular employment relationships where the employer contracts their services to a third party which effectively controls the employees work.

The former Labour government announced that the Employment Relations Act 2000 would be amended to strengthen the rights of employees who are in these sorts of triangular employment relationships. If this amendment were to go ahead employees in this situation who belong to a union would be entitled to terms and conditions at least as favourable as those enjoyed by unionised workers employed directly by the secondary employer under a collective agreement. Also both primary employers and employees would be able to join a secondary employer in any grievance proceeding. ${ }^{30}$

The former Labour government also announced that it would be putting in place measures to strengthen employment protections for casual work $^{31}$ Research on casual workers and their employers shows a lack of knowledge about employment rights and obligations and casual workers often have "limited access to holiday, sick leave, training, skill development and career pathways and that casual work [often] causes undue intrusion into family life, limiting the ability to budget and plan ahead"32 Accordingly, the Department of Labour was instructed to develop a Code of Employment Practice for Casual and Non Standard Employment and awareness raising campaign aimed to increase workers knowledge of their statutory rights in the workplace was also planned

It is not clear, at this time, whether these planned measures will go forward. It is suggested that since there is evidence to suggest that agency hire workers and casual workers are being disadvantaged in the workplace, failure to proceed with these measures, or similar ones, must be viewed as not in keeping with the rights and the equality that all workers are supposed to enjoy under Articles 7 and 8.

\section{Prisoners}

It is also questionable whether the terms and conditions under which New Zealand prisoners labour are compatible with the spirit of New Zealand's international obligations. Prisoners are not defined as employees and do not have the same access to collective bargaining, rights, and remedies as free workers do. They work for a small "incentive allowance" which ranges from $20 \mathrm{c}$ to $60 \mathrm{c}$ an hour. It is surely arguably that this is not "a fair wage" which provides "a decent living for themselves and their families" as required by Article 7 or as equitable remuneration as required by Rule 76 (1) the UN Standard Minimum Rules for the Treatment of Prisoners. ${ }^{33}$

\section{Ratifying the final Two Core Conventions}

One final area in which it is suggested New Zealand could do better lies in the fact that two fundamental International Labour Organisation Conventions, 87 on Freedom of Association and Protection of the Right to organise $^{34}$ and 138 on the Minimum Age for Employment ${ }^{35}$ remain unratified. Despite non ratification New Zealand has "an obligation arising from the very fact of membership in the [ILO] to respect, to promote and to realize, in good faith...the principles concerning the fundamental right which are the subject of [the core Conventions] ${ }^{36}$ However, it should be noted, largely due to the fact that these Conventions have been identified by the ILO's governing body as fundamental rights, they have been ratified by the vast majority of ILO member nations ${ }^{37}$ Therefore, ongoing movement towards ratification of these Conventions would seem to be desirable in terms of New Zealand maintaining its credibility and status in the international community of nations. It would also be consistent with the obligation of progressively realising the rights conferred by Article 6.7 and 8 .

\section{Conclusion: Where Do We Go From Here?}

\section{Summary}

To summarise some key points made in this paper: 
The rights discussed here have the potential to contribute a great deal to enhancing the working and living conditions of New Zealand both as legal and rhetorical instruments.

The right to work is a right to freely chosen, non coerced work. New Zealand needs to be careful about putting prisoners to work particularly if the prison system becomes more privatised.

Some groups still suffer from discrimination in New Zealand, not only in accessing work but also in enjoying equal opportunities and the rights which should attach to work.

The right to work includes a right to protection from unfair dismissal.

Ongoing progress towards ratifying the two outstanding core ILO Conventions is desirable.

\section{Areas for future work}

The key points raised by this paper, suggest some directions for future research.

- Does the recent announcement of National's intention to rush through of the 90 day probation bill under urgency constitute a deliberately regressive measure which impedes the goal of realisation of the right to work?

Empirical research on the likely effect efficacy of rights arguments, concerning workers terms and conditions, as opposed to business case arguments on the New Zealand business community would be interesting.

Empirical research on the conditions prison labour in New Zealand to determine the degree to which there is compliance with the requirement that work should be freely chosen may raise some important issues.

Comparative legal research on how other countries address the legal status of temps and casual workers to ensure that they receive the protections they ought to be entitled to would be interesting.

What are the impediments to New Zealand ratifying the two fundamental International Labour Organisation Conventions, 87 on Freedom of Association and Protection of the Right to organise $^{38}$ and 138 on the Minimum Age for Employment. How does New Zealand differ from all the other first world countries who have ratified the Conventions?

\section{Notes}

1. See also Article 24 of the Universal Declaration of Human Rights which establishes the right to rest and leisure, including reasonable limitation of working hours and periodic holidays with pay.
2. The essence of these rights is reflected in Article 23.1 of the Universal Declaration of Human Rights "Everyone has the right to work, to free choice of employment, to just and favourable conditions and to protection against unemployment. For further information about relevant international rights see Human Rights Commission, Human Rights in New Zealand Today, (Auckland, September, 2004), http://www.hrc.co.nz/report/chapters/chapter16/wo rk01.html, Chapter 16 "The Right to Work" Sections 1-2.

3. See the Limburg Principles on the Implementation of ICESR Principle 72 (f)

4. Office of the High Commissioner on Human Right Fact Sheet No. 16 (Rev 1) The Committee on Economic and Social Rights http://www.unhchr.ch/html/menu6/2/fs16.htm\#8

5. United Nations Committee on Economic, Social and Cultural Rights, Article 6 of the International Covenant on Economic, Social and Cultural Rights The Right to Work General Comment No 18, 35th session., November 7-25, 2005, http://www.unhchr.ch/tbs/doc.nsf/0/493bee 380934 58c0c12571140029367c/\$FILE/G0640313.pdf, Paragraph 50.

6. J Servais, "Globalization and Decent Work Policy: Reflections Upon A New Legal Approach," International Labour Review 143, no.1-2 (2004): $185,188$.

7. Ibid., 4.

8. Ibid., $1-2$.

9. Compa, Lance: "Corporate Social Responsibility and Workers' Rights," Comparative Labor Law and Policy Journal 30, no. 1(2008): 1, 10.

10. Ian Roper, Ian Cunningham, Phil James, "Promoting Family Friendly Policies: is the Basis of the Governments Ethical Standpoint Viable?," Personnel Review 32, no. 2 (2003): 211. This article reports on a survey of how Human Resource (HR) Practitioners are responding to the current UK Governments "business case" approach to promoting family friendly policies. The authors suggest that, on the basis of their findings, if the United Kingdom Government seriously wishes to make employment more family-friendly, it needs to place greater emphasis on a social justice and rights based approach to the issue.

11. All of the information in this paragraph is extracted from the Human Rights Commission, Statement of Intent (Auckland, 2007) Section 4, "The Right to Work," Current Situation 
12. United Nations Committee on Economic, Social and Cultural Rights, Article 6 of the International Covenant on Economic, Social and Cultural Rights: The Right to Work, General Comment No 18, 35th session., November 7-25, 2005, http://www.unhchr.ch/tbs/doc.nsf/0/493bee 380934 $58 \mathrm{c} 0 \mathrm{c} 12571140029367 \mathrm{c} / \$ F I L E / G 0640313$, pdf Para 11

13. United Nations Committee on Economic, Social and Cultural Rights, Report on the Eighteenth and Nineteenth Sessions, Supplement Number 2, 1999 , 405. "The Committee notes with concern that at least six provinces in Canada (including Quebec and Ontario) have adopted "workfare" programmes that either tie the right to social assistance to compulsory employment schemes or reduce the level of benefits when recipients... assert their right to choose freely what type of work they wish to do."

14. Press Release: the Hon Phil Goff, Minister of Corrections New Zealand Government "Photocopier Assembly Initiative for Prisoners, "17 July, 2008.

15. Ibid.

16. Ironically goods manufactured wholly or in part by prison labour are prohibited imports in New Zealand Customs and Excise Act 1996 No 27 Schedule 1 Prohibited Imports s 54(1) yet prisoner made goods are permitted to be manufactured and sold within New Zealand.

17. International Labour Organisation, The Director General's Global Report to the ILO Conference. Stopping Forced Labour, $89^{\text {th }}$ sess., 2001 para 191.

18. Ibid., para. $195-96$ "With prisoners already deprived of their liberty, there is an evident risk that private hiring of prison labour can involve exploitation, thus negating any pretence of the exercise of free will,"

19. ILO Convention (No. 29) Concerning Forced Labour 1938 (ratified by New Zealand 29/03/1938) Article 2C. See also Article 4 "The competent authority shall not impose or permit the imposition of forced or compulsory labour for the benefit of private individuals"

20. Simon Collins, Prisoners Paid 20 Cents an Hour to Pick Fruit," New Zealand Herald, February 28. 2006.

21. Press Release: the Hon Phil Goff, Minister of Corrections, New Zealand Government "Photocopier Assembly Initiative for Prisoners," 17 July 2008.
22. Stuart Dye, "Prisoners Help Build Luxury City Tower," New Zealand Herald, January 22, 2004.

23. The ILO noted that The International Confederation of Free Trade Unions (ICFTU) has criticised a number of aspects of prison work schemes pointing to instances of prisoners who refused such work losing their chance for early release and being deprived of privileges and time outside their cells. International Labour Organisation, The Director General's Global Report to the ILO Conference, Stopping Forced Labour, 89 $9^{\text {th }}$ sess., 2001, para 193

24. Ibid., para 196.

25. International Labour Organisation, Committee of Experts on the Application of Conventions and Recommendations Individual Observation Concerning Convention No 29, Forced Labour 1930 Australia (ratification 1932) (Geneva, 1999)

26. Human Rights Commission, Human Rights in New Zealand Today, (Auckland, September, 2004), http://www.hrc.co.nz/report/chapters/chapter 16/wo rk01.html, Chapter 16 "The Right to Work" Section 6

27. Human Rights Commission, Human Rights in New Zealand Today, (Auckland, September, 2004), http://www.hrc.co.nz/report/chapters/chapter16/wo rk01.html, Chapter 16 "The Right to Work" Section 6

28. Ministry of Women's Affairs, New Zealand's Sixth Report on the Implementation of the United Nations Convention on the Elimination of All Forms of Discrimination Against Women (Wellington, March 2006), http://www.mwa.govt.nz/news-andpubs/publications/international/cedawreport.html\#artl 1

29. Human Rights Commission, New Zealand Census of Women's Participation (Auckland, March 2008),

http://www.hrc.co.nz/hrc new/hrc/cms/files/docu ments/28-Mar-2008 12-59

39_2008_Census_of_Womens_Participation.pdf

30. Author Unknown, "New Bill - Employment Relations Amendment (No 3)," The Capital Letter 31, no. 35 8-9 (2008): 8-9.

31. Press Release: Trevor Mallard, "Stronger Protections for Casual and Temp Workers" 22 July 2008

32. Ibid.

33. International Labour Organisation, The Director General's Global Report to the ILO Conference, Stopping Forced Labour, $89^{\text {th }}$ sess., 2001, 59, para 193. "Workers organisations in... New 
Zealand...have... expressed serious concern over wage rates and/or prisoners terms and conditions of work, especially when private enterprise is involved."

34. International Labour Organisation, Country Baseline Under the ILO Declaration Annual Review (2000-2008): New Zealand, Freedom of Association and the Effective Recognition of the Right to Collective Bargaining, 7 "The ILO Declaration Expert-Advisers were concerned that the Government of New Zealand...had indicated the current impossibility to ratify C. 87 , without further justification."

35. International Labour Organisation, Country Baseline Under the ILO Declaration Annual Review (2000-2008): New Zealand, The Effective Abolition of Child Labour, 2, "The Government is still in the process of assessing whether or not it can ratify C. 138 "

36. International Labour Organisation, ILO Declaration on Fundamental Principles and Rights at Work, 86th sess., June, 1998., Clause 2.

37. International Labour Organisation, Ratifications of the Fundamental Human Rights Conventions by Country, http://www.ilo.org/ilolex/ english/docs/declworld.htm

38. International Labour Organisation, Country Baseline Under the ILO Declaration Annual Review (2000-2008): New Zealand, Freedom of Association and the Effective Recognition of the Right to Collective Bargaining, 7 "The ILO Declaration Expert-Advisers were concerned that the Government of New Zealand...had indicated the current impossibility to ratify C. 87 , without further justification."

\section{References}

Compa, Lance. (2008) "Corporate Social Responsibility and Workers' Rights." Comparative Labor Law and Policy Journal 30, no. 1: 1-10.

Roper, I. and Ian Cunningham and Phil James. (2003). "Promoting Family Friendly Policies: is the Basis of the Governments Ethical Standpoint Viable?" Personnel Review 32, no 2: 211-230.

Servais, J. (2004). "Globalization and Decent Work Policy: Reflections Upon A New Legal Approach." International Labour Review 143, no.1-2: 185-207.

Author Unknown. (2008). "New Bill - Employment Relations Amendment (No 3)." The Capital Letter 31, no. 35: 8-9.

Human Rights Commission. New Zealand Census of Women's Participation. Auckland, March 2008. http://www.hrc.co.nz/hrc new/hrc/cms/files/docu ments/28-Mar-2008 12-59

39_2008_Census_of_Womens_Participation.pdf

Human Rights Commission. Human Rights in New Zealand Today. Auckland, September, 2004. http://www.hrc.co.nz/report/chapters/chapter16/wo rk01.html, Chapter 16 "The Right to Work"

Human Rights Commission. Annual Report. Auckland, 2007 "Children and Young People"

Human Rights Commission, Statement of Intent. Auckland, 2007.

International Labour Organisation. Ratifications of the Fundamental Human Rights Conventions by Country. http://www.ilo.org/ilolex/ english/docs/declworld.htm

International Labour Organisation. Declaration on Fundamental Principles and Rights at Work. 86th sess., June, 1998.

International Labour Organisation. The Director General's Global Report to the ILO Conference. Stopping Forced Labour. 89 $9^{\text {th }}$ sess., June, 2001.

International Labour Organisation. Country Baseline Under the ILO Declaration Annual Review (20002008): New Zealand, Freedom of Association and the Effective Recognition of the Right to Collective Bargaining.

International Labour Organisation. Country Baseline Under the ILO Declaration Annual Review (20002008): New Zealand, The Effective Abolition of Child Labour.

International Labour Organisation, Committee of Experts on the Application of Conventions and Recommendations Individual Observation Concerning Convention No 29, Forced Labour 1930 Australia (ratification 1932). Geneva, 1999.

Ministry of Women's Affairs. New Zealand's Sixth Report on the Implementation of the United Nations Convention on the Elimination of All Forms of Discrimination Against Women Wellington, March 2006. http://www.mwa.govt.nz/news-andpubs/publications/international/cedawreport.html\#art1 1

Ministry of Social Development, New Zealand Living Standards. Wellington: Centre for Social Research and Evaluation, 2006.

Office of the High Commissioner on Human Rights Fact Sheet No. 16 (Rev 1) The Committee on Economic and Social Rights http://www.unhchr.ch/html/menu6/2/fs $16 . h t m \# 8$ 
United Nations Economic and Social Council. Committee on Economic, Social and Cultural Rights. Article 6 of the International Covenant on Economic, Social and Cultural Rights The Right to Work General Comment No 18. 35th session., 7-25 November, 2005.

http://www.unhchr.ch/tbs/doc.nsf/0/ 493bee38093458c0c12571140029367c/\$FILE/G0 640313.pdf

United Nations Committee on Economic, Social and Cultural Rights. Report on the Eighteenth and Nineteenth Sessions, Supplement Number 2. 1999.

\author{
Author \\ Amanda Reilly \\ Lecturer \\ School of Accounting and Commercial Law \\ Victoria University of Wellington \\ P.O. Box 600 \\ Wellington 6140 \\ Amanda.Reilly@vuw.ac.nz
}

